\title{
Interaction between different pre- and postharvest treatments on shelf life extension of 'Oregon Spur' apple
}

\author{
Hare KRISHNA $^{1,2 \star}$, Biswajit DAS ${ }^{1}$, Brij Lal ATtRI ${ }^{1}$, Akhilesh KUMAR ${ }^{1}$, Nazeer AHMED ${ }^{3}$
}

\author{
${ }^{1}$ Cent. Inst. Temp. Hortic.-Reg \\ Stn., Mukteshwar-263 138, \\ Uttarakhand, India, \\ kishun@rediffmail.com \\ ${ }^{2}$ Present address: Cent. Inst. \\ Arid Hortic. (ICAR), Sri \\ Ganganagar Road, NH-15, \\ Beechwal, Bikaner-334 006, \\ Rajasthan, India \\ ${ }^{3}$ Cent. Inst. Temp. Hortic., \\ Srinagar-190 007, \\ Jammu \& Kashmir, India
}

* Correspondence and reprints

Received 2 February 2011 Accepted 14 April 2011

Fruits, 2012 , vol. 67 , p. $31-40$ (C) 2011 Cirad/EDP Sciences All rights reserved DOI: $10.1051 /$ fruits/2011064 www.fruits-journal.org

RESUMEN EsPañol, p. 40
Interaction between different pre- and postharvest treatments on shelf life extension of 'Oregon Spur' apple.

Abstract - Introduction. Fruit quality characteristics are governed by preharvest factors, mainly climate, nutrition and plant bio-regulators, of which the latter two can easily be manipulated in the grower's interest. Likewise, the postharvest treatments with the best performance can maintain quality during storage and distribution. Therefore, it is important to embrace a holistic approach to combine the pre- and postharvest practices in view of attaining maximum quality and satisfaction at the consumer level. Materials and methods. Various combinations of mineral nutrients (calcium and boron) and bio-regulators (salicylic acid and gibberellic acid) were applied at the pre- and postharvest stages of apple fruits to study their influence on postharvest behavior of these fruits during 60 days of storage under ambient conditions. Results and discussions. Among the different treatments tried, fruits treated with either salicylic acid or calcium showed significant improvement with regards to improved physico-chemical characteristics and reduced fruit infection percentage. Integration of pre- and postharvest application of chemicals was verified as the most effective choice for the improvement of shelf life of apple fruits amongst the treatment combinations applied either at the pre- or postharvest stage. The application of salicylic acid in combination with calcium or boron renders an alternative to the use of fungicides to control decay during apple fruit storage.

India / Malus / fruits / quality / storage / postharvest losses / preharvest treatment / postharvest treatment / plant growth substances / keeping quality

Effet de différents traitements appliqués avant et après récolte sur l'extension de la durée de vie de pommes 'Oregon Spur'.

Résumé - Introduction. Les caractéristiques de qualité des fruits sont régies par certains facteurs intervenant avant leur récolte, principalement le climat, la nutrition et les bio-régulateurs des plantes ; ces deux derniers éléments peuvent facilement être manipulés pour aider le producteur. De même, certaines combinaisons de traitements après récolte sont aptes à maintenir la qualité des fruits pendant le stockage et la distribution. Il en résulte qu'il serait important d'adopter une approche globale permettant de combiner les pratiques avant ou après récolte en vue d'obtenir une qualité maximale et la satisfaction du consommateur. Matériel et méthodes. Diverses combinaisons d'éléments minéraux (calcium et bore) et de bio-régulateurs (acide salicylique et acide gibbérellique) ont été appliquées à des lots de pommes avant et après récolte pour étudier leur influence sur le comportement après récolte de ces fruits au cours d'un stockage de 60 jours dans des conditions ambiantes. Résultats et discussion. Parmi les différents traitements essayés, les fruits traités soit avec de l'acide salicylique soit avec du calcium ont montré une amélioration significative de leurs caractéristiques physico-chimiques et leur taux d'infection a été réduit. Parmi tous les traitements testés, les combinaisons de produits chimiques appliquées avant et après récolte se sont avérées être les plus appropriées à une amélioration de la durée de conservation des pommes. L'application de l'acide salicylique en combinaison avec du calcium ou du bore permettrait de pallier l'utilisation de fongicides pour lutter contre la dégradation des pommes pendant leur stockage.

Inde / Malus / fruits / qualité / stockage / perte après récolte / traitement avant récolte / traitement postrécolte / substance de croissance végétale / aptitude à la conservation 


\section{Introduction}

Owing to the beautiful appearance, crispy flesh, pleasant flavor and taste, and nutraceutical values of apples, consumers have a propensity towards these fruits and are willing to pay higher prices for good quality fruits. However, during the harvesting period, growers do not fetch higher prices due to a glut in the market. Therefore, there is a need to lengthen the supply of apple fruits by extending their postharvest life.

Fruit quality and shelf life of apple fruits are governed by the nutritional status of fruit trees, particularly boron (B) and calcium (Ca), deficiency of which in apple leads to early fruit softening, high incidence of physiological disorders such as internal breakdown, bitter pit, high respiration, ethylene production and fruit decay [1]. Additionally, fruits poor in $\mathrm{Ca}$ and $\mathrm{B}$ are sensitive to sunburn, splitting and rotting, and have a short storage life [2, 3]. Therefore, reduction of postharvest spoilage and enhancement of the shelf life of fruits can also be achieved by increasing the $\mathrm{Ca}$ and $\mathrm{B}$ contents of fruits. The most effective orchard treatment for increasing fruit $\mathrm{Ca}$ and $\mathrm{B}$ concentration is foliar application of these elements [2, 3]. There are a few bio-regulators such as gibberellic acid $\left(\mathrm{GA}_{3}\right)$ [4] and salicylic acid [5], which are thought to affect the shelf life of fruits. Application of $\mathrm{GA}_{3}$ has been observed to improve fruit quality during storage [6], and retard ripening [7] and spoilage of fruits [4]. One of the most important considerations for extending shelf life of fruits is circumventing fruit spoilage caused by various pathogenic fungi during postharvest storage. Primarily, postharvest diseases are controlled by the use of fungicides [8, 9]. However, there is a need for alternative practices for suppression of diseases during storage to reduce health-related risks to consumers. Research has shown the promise of application of calcium and boron for resistance of fruits to pathogenic fungi during storage [1, 9-11]. Though the application of a single nutrient or growth regulator has been found beneficial for improving fruit quality and extending the shelf life of fruits, their combined application yielded better results [11]. The purpose of our investigation was to determine the effects of pre- and postharvest application of different nutrients ( $\mathrm{Ca}$ and $\mathrm{B}$ ) and bio-regulators and their combinations on apple shelf life and fruit quality at harvest and storage.

\section{Materials and methods}

Our study was carried out in the experimental farm of the Central Institute of Temperate Horticulture-Regional Station, Mukteshwar, India, on 10-12-year-old 'Oregon Spur' apple trees trained on a modified leader system, spaced $5 \mathrm{~m}$ between rows, and planted on a sandy-loam soil. During the experiment only N, P and $\mathrm{K}$ were applied at the rate of 700-840 g, 350-420 g and 700-840 g per tree, respectively, depending upon the age of the plant.

The experiment was conducted with a randomized complete block design with three replications. The experiment consisted of three preharvest treatments, two postharvest treatments and six-combinations of pre- and postharvest treatments, besides control (table I), with 10 trees per replication.

The concentrations of the different nutrients and bio-regulators used in the experiment were $\mathrm{GA}_{3}$ at $30 \mathrm{mg} \cdot \mathrm{L}^{-1}$, Ca EDTA at $500 \mathrm{mg} \cdot \mathrm{L}^{-1}$, boric acid at $0.1 \%$, fungicides (Bavistin + Mancozeb at 0.05\% each) and salicylic acid at $400 \mathrm{~m} \cdot \mathrm{L}^{-1}$. Trees sprayed with water served as control.

The trees were sprayed thrice at 10-day intervals. The first spray was done 90 days after full bloom (DAFB) and the fruits were harvested 120 days after full bloom, i.e., 10 days after the last spray. All the treatments were applied with a handgun to runoff; 400 fruits from each treatment were hand-harvested in the first week of August. The mature fruits harvested at the optimal stage of flavor development, suitable for the fresh market and free from any apparent physiological and pathological disorders, were chosen and washed with double-distilled water and then air-dried. Each treatment during the season of study was replicated thrice; each replicate was represented by 


\section{Table I.}

Details of pre- and postharvest treatments applied to apple fruits to assess the effect of various combinations of elements on the quality characteristics of fruits at harvest and during storage.

\begin{tabular}{|c|c|c|c|c|c|c|c|}
\hline \multirow[t]{2}{*}{ Treatment } & \multicolumn{4}{|c|}{ Preharvest spray } & \multicolumn{3}{|c|}{ Postharvest } \\
\hline & $\mathrm{GA}_{3}$ & Ca EDTA & Boric acid & Salicylic acid & Ca EDTA dip & Salicylic acid dip & Fungicide application \\
\hline T1 & $x$ & $x$ & & & & & \\
\hline T2 & $x$ & & $x$ & & & & \\
\hline T3 & $x$ & & & $x$ & & & \\
\hline T4 & & & & & $x$ & & $x$ \\
\hline T5 & & & & & & $x$ & \\
\hline T6 & $x$ & $x$ & & & $x$ & . & $x$ \\
\hline T7 & $x$ & & $x$ & & $x$ & & $x$ \\
\hline T8 & $x$ & & & $x$ & $x$ & & $x$ \\
\hline T9 & $x$ & $x$ & & & & $x$ & \\
\hline T10 & $x$ & & $x$ & & & $x$ & \\
\hline T11 & $x$ & & & $x$ & & $x$ & \\
\hline T12 & & & & I: preharvest & and posthar & est dip of water & \\
\hline
\end{tabular}

three corrugated fiberboard (CFB) boxes; each box was lined with butter paper and contained $3 \mathrm{~kg}$ of fruits. The boxes were stored at ambient temperature $\left(20-25^{\circ} \mathrm{C}\right)$ and relative humidity (80-85\%). All the observations were made at harvest (for pretreatments) or just before storage (for postharvest treatments) and during storage at regular intervals of 10 days for 60 days.

For the determination of fruit infection percentage, on each sampling apple, the decayed fruits were discarded and counted. The number of such discarded fruits relative to the initial number of fruits per sample was estimated and the fruit decay percentage was calculated. The firmness of the fruit was measured with an Effegi penetrometer (Model FT-327) using a plunger of $8 \mathrm{~mm}$ in diameter. The physiological loss in fresh weight was estimated by weighing fruits individually after harvest. The fruits were labeled and stored. At each sampling time (10-day intervals up to 60 days), starting from day 0 of the storage, the same fruits were weighed. Weight loss was expressed as a percentage of the original fresh weight of the fruits. Vitamin $\mathrm{C}$ ( $\mathrm{mg}$ ascorbic acid) was determined and estimated per $100 \mathrm{~mL}$ juice, while titratable acidity was determined in well-mixed juice $(20 \mathrm{~mL})$ by titration against $\mathrm{NaOH} \quad(0.1 \mathrm{~N})$ using phenolphthalein as an indicator [12]. The acidity percentage was calculated (as $g$ malic acid per $100 \mathrm{~g}$ pulp). The total soluble solids were determined in ${ }^{\circ}$ Brix using Abbe's hand refractometer calibrated at $20^{\circ} \mathrm{C}$. Reducing, non-reducing and total sugars were determined according to the methods of the Association of Official Analytical Chemists [12]. The appearance, taste, flavor and texture of samples were evaluated organoleptically by a panel of 10 judges, giving scores out of hundred. The panelists washed their mouths with water intermittently to evaluate samples.

Data obtained for two years were pooled and subjected to analysis of variance. Least significant differences (LSD) were used to differentiate the values obtained.

\section{Results and discussion}

Among the different treatments (pre- and postharvest), preharvest sprays of $\left[\mathrm{GA}_{3}\right.$ + salicylic acid] thrice, at an interval of 10 days beginning one month before harvest, was found to be the most suitable in respect of increased fruit firmness, total soluble solids (TSS), ascorbic acid, and reducing and total sugars, and they decreased fruit infection and physiological loss in weight. Likewise, among the postharvest treatments, 


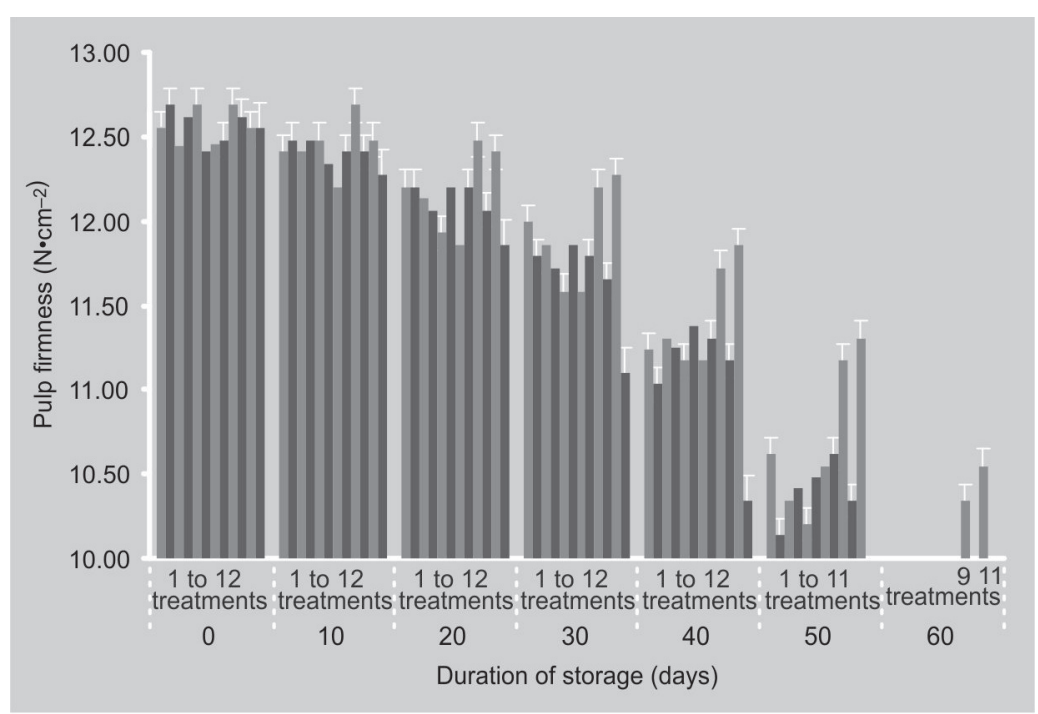

Figure 1.

Pattern of fruit firmness in apple fruits during storage as influenced by different treatments (see table I). Vertical bars represent standard error of the means.

\section{Figure 2.}

Effect of different treatments (see table I) on physiological loss in weight of apple fruits during storage. Vertical bars represent standard error of the means.

postharvest salicylic acid dip was found to be the best. The treatments comprising preharvest spray of $\left[\mathrm{GA}_{3}+\mathrm{Ca}\right.$ EDTA $]+$ postharvest salicylic acid dip followed by preharvest spray of $\left[\mathrm{GA}_{3}+\right.$ salicylic acid $]+$ postharvest salicylic acid dip were shown to be superior to all other combinations for the aforementioned quality parameters.

Pulp firmness is an important quality attribute as it has direct implications on storage potential, resistance to decay organisms, mechanical injury and acceptability to consumers [13]. The results showed that the fruit firmness decreased commensurate with the advancement of the storage period

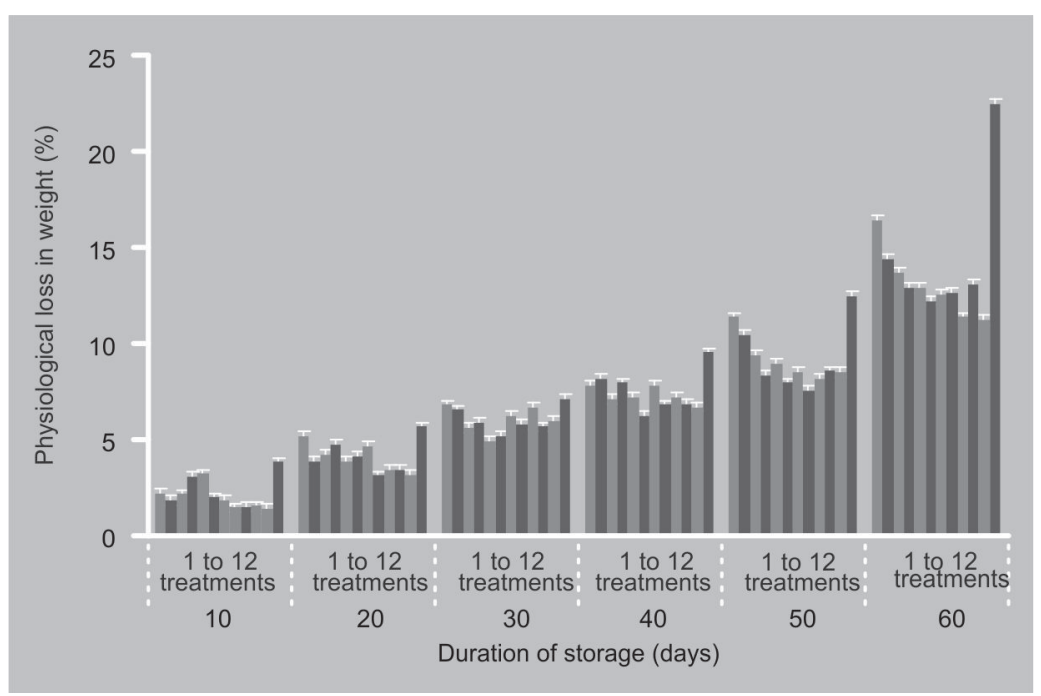

(figure 1); however, the decline was significantly slowed down by the treatments comprising preharvest spray of $\left[\mathrm{GA}_{3}+\mathrm{Ca}\right.$ EDTA] + postharvest salicylic acid dip treatment (T9), followed by preharvest spray of $\left[\mathrm{GA}_{3}\right.$ + salicylic acid] + postharvest salicylic acid dip (T11). The treated fruits were significantly firmer as compared with the untreated control (T12). The maintenance of higher firmness by application of $\mathrm{Ca}, \mathrm{B}$, gibberellic acid and salicylic acid may be due to the role of these compounds in maintaining cellular organization and regulating enzyme activities $[14,6]$. The percentage of physiological loss in weight is an important parameter in maintaining the flesh firmness of the fruits. The loss in fruit weight during storage could primarily be attributed to losses in moisture through physiological processes such as transpiration and respiration [13, 15]. The postharvest loss of fruit weight was significantly lowered by treating the fruits with bioregulators such as $\mathrm{GA}_{3}$ and salicylic acid and minerals such as $\mathrm{Ca}$ and $\mathrm{B}$ at either the preor postharvest stage (figure 2). The physiological loss in weight was most significantly circumvented by fruits treated with preharvest spray of $\left[\mathrm{GA}_{3}+\mathrm{Ca}\right.$ EDTA $]+$ postharvest salicylic acid dip treatment followed by preharvest spray of $\mathrm{GA}_{3}+$ salicylic acid] + postharvest salicylic acid dip (figure 2). This suggests that the fruits which received the treatment with salicylic acid or salicylic acid in combination with calcium might have had a reduced rate of degradative physiological processes, which resulted in the least loss in fruit weight. Earlier, Rajkumar et al. and Horvitz et al. reported that the preharvest application of $\mathrm{GA}_{3}$ and salicylic acid slowed down the process of ripening in papaya and peaches, respectively, by retarding the preclimacteric respiration rate, and subsequently ethylene production $[4,5]$.

The TSS content registered a rapid increase in all the treated fruits during storage as compared with control (figure 3). Increase in TSS content indicates conversion of polysaccharides present in fruits into soluble sugars by the action of various hydrolyzing enzymes. Fruits treated with mineral nutrients and bio-regulators showed a remarkably higher TSS over control, which might be due to quick metabolic 
transformation into soluble compounds and more conversion of polysaccharides into reducing sugars. The results are in concurrence with Conway et al. [1], Kumar et al. [14], and Kathyren and Brannen [16]. The TSS content registered a rapid increase in all the treatments initially as a result of conversion of starch into sugars; thereafter, a decrease was observed earlier, i.e., at 30 days in treatments which did not include salicylic acid, while, in salicylic acid-treated fruits, the decline was delayed to 40 days (figure 3). Similar trends were noted for reducing sugars and total sugars as well (figure 3). Though non-reducing sugars were found to decrease throughout the experimentation period, the decline was more prominent at 30 days in non-salicylic acid treatments and at 40 days in salicylic acid treatments (figure 4). The reduction in reducing, nonreducing and total sugars at 30 and 40 days of storage may be attributed to the catabolism of sugars by respiration [17]. The delayed reduction in sugar content in salicylic acid-treated fruits could be ascribed to inhibition of the respiration rate by the action of salicylic acid, as reported by Rong et al. [18] and Han et al. [5] in mango and peaches, respectively. Increased sugar levels at 40 to 60 days of storage points towards hydrolysis of starch in fruits.

Regarding the effect of bio-regulators and nutrients on the total acidity percentage, the results obtained showed that untreated control fruits (T12) still had low acidity for a period longer than that of treated ones (figure 5). Total acidity appeared to decrease during the storage period. Thus, as found for many fruits [19], a consumption of organic acids also occurs during storage of apples. The rate of decline was more conspicuous at 40 days for salicylic acid-treated fruits and 30 days for non-salicylic acid-treated fruits. Preharvest salicylic acid spray and postharvest dip resulted in higher acidity than either Ca- or B-treated fruits (figure 5). This result corroborates the findings of Dris and Niskonen [20]. The treatment comprising combinations of [Ca EDTA + salicylic acid] was on par with the salicylic acid-treated fruits (figure 5). Han and $\mathrm{Li}$ reported that application of salicylic acid resulted in increased content of soluble solids and total acidity of apple

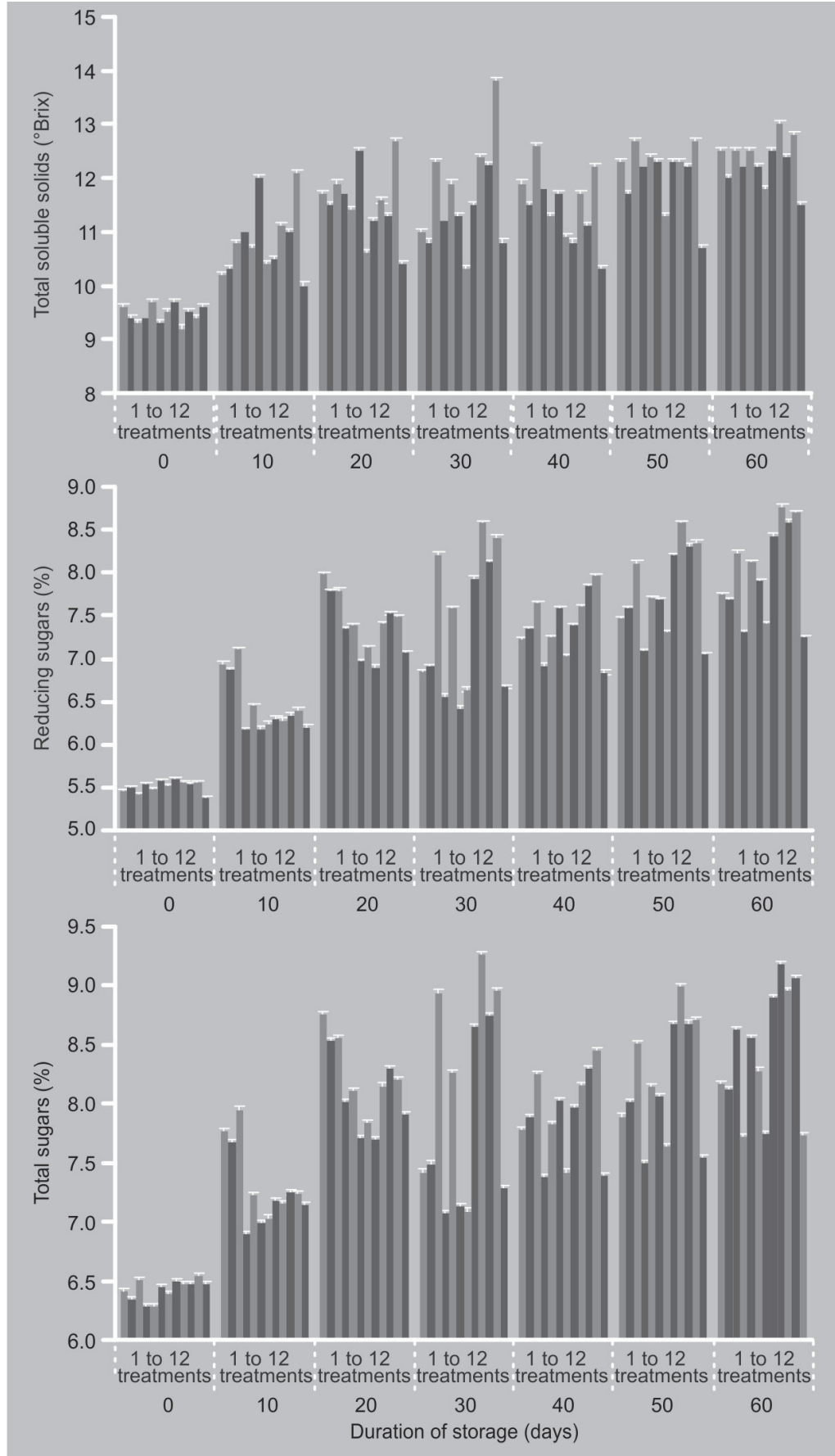

fruits at the end of 31 days of storage without affecting the fruit firmness [21].

For ascorbic acid content during the storage period, there was an increase in ascorbic acid at 10 days of storage (figure O). Thereafter, ascorbic acid content decreased
Figure 3.

Effect of different treatments(see table I) on total soluble solid, reducing sugar and total sugar contents of apple fruits during storage. Vertical bars represent standard error of the means. 


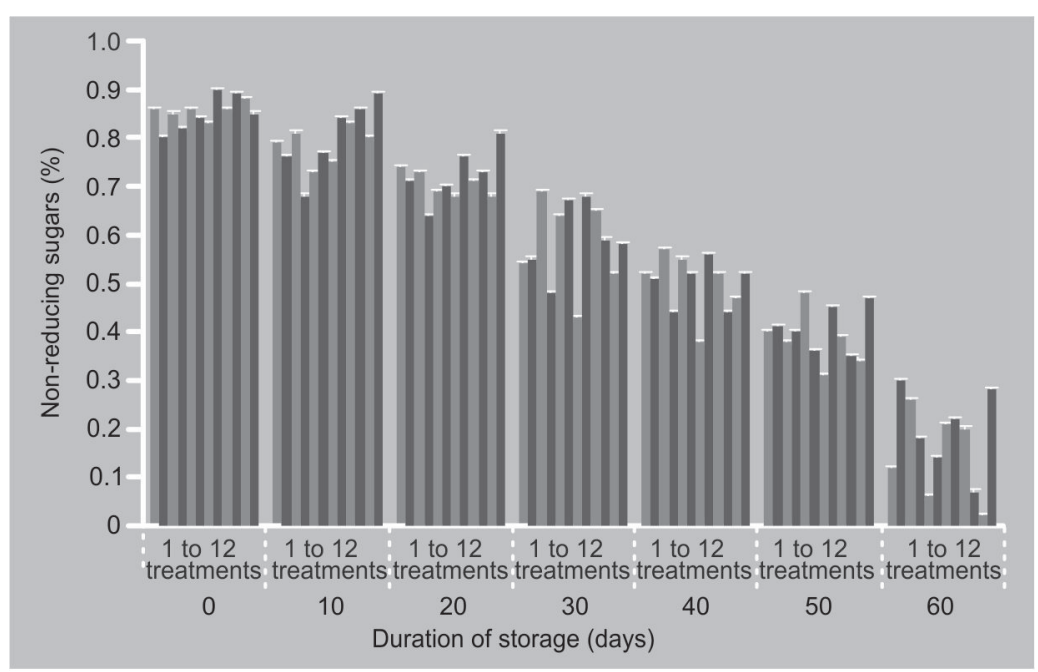

Figure 4.

Variations in non-reducing sugars as influenced by different treatments (see table I) during storage. Vertical bars represent standard error of the means.

\section{Figure 5.}

Effect of different treatments (see table I) on total acidity of apple fruits during storage. Vertical bars represent standard error of the means.

throughout the storage period, although the dynamics differed from treatment to treatment. The treatments with the highest ascorbic acid at 10 days of storage were preharvest spray of $\left[\mathrm{GA}_{3}+\right.$ salicylic acid $]+$ postharvest salicylic acid dip (T11) followed by preharvest spray of $\left[\mathrm{GA}_{3}+\mathrm{Ca}\right.$ EDTA $]$ + postharvest salicylic acid dip (T9); however, this treatment comprising preharvest spray of $\left[\mathrm{GA}_{3}+\mathrm{Ca}\right.$ EDTA $]+$ postharvest salicylic acid dip took a lead at the end of the study period. Kher and Bhat [22] also observed an increase, up to 3 days of storage, in ascorbic acid content of guava fruits treated with $\mathrm{GA}_{3}$ and other growth regulators, which thereafter decreased continuously during the entire storage period. The reduction in ascorbic acid content was sig-

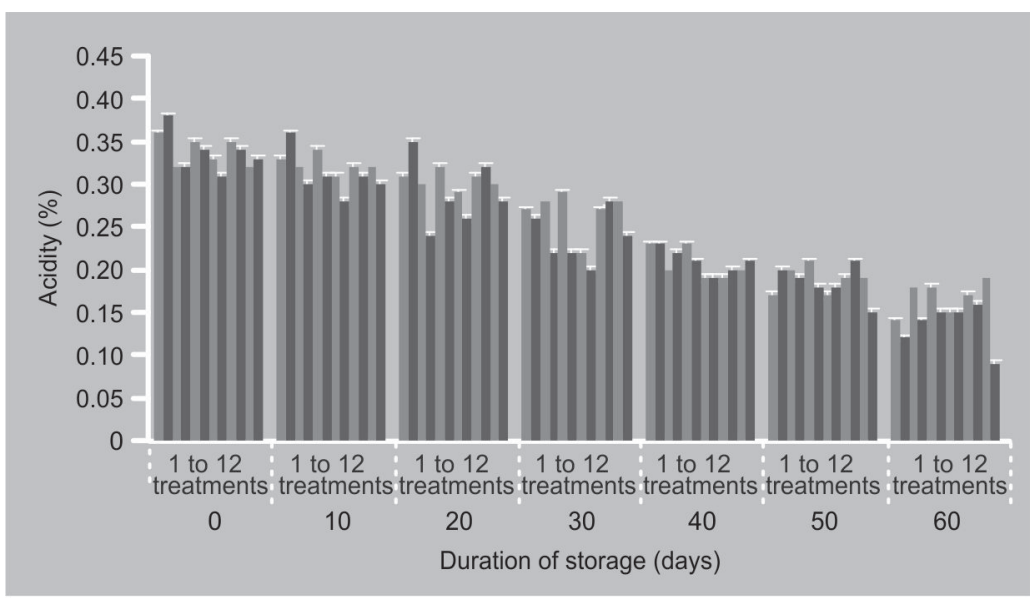

nificantly curtailed by all the treatments, comprising different combinations of preand/or postharvest applications of minerals and bio-regulators, over untreated control fruits during the study period. The results are in agreement with those obtained by Kumar et al. [4]. Singh et al. reported that preharvest foliar application of calcium and boron was quite useful for improving quality attributes such as ascorbic acid content of strawberry fruits [23]. Likewise, Karlidag et al. reported the positive influence of salicylic acid on TSS and ascorbic acid content of strawberry fruits [24].

Application of common fungicides for controlling postharvest diseases is seemingly less practised nowadays owing to the progressive development of fungicide resistance by pathogens, and increasing public concern about fungicide residues in food and their potential health hazards [8]. Therefore, adoption of new strategies for control of postharvest diseases is inevitable. Induction of resistance to pathogen infection has been indicated as a promising approach for controlling postharvest diseases of fruit. Studies have shown that salicylic acid treatment can enhance disease resistance in treated fruits $[8,25]$. In our study too, salicylic acid might have helped prevent pathogenic infection by eliciting the defense response in treated fruits and thereby preventing pathogenic infection $[10,25]$, as evidenced by less spoilage in treated fruits (figure 7). Likewise, enhancing the content of nutrients viz. calcium and boron in apple fruits can be very beneficial in maintaining fruit quality during storage. Pre- or postharvest use of $\mathrm{Ca}$ [1] and B [9] has shown promise in reducing decay caused by Penicillium expansum Link., Botrytis cinerea Pers.:Fr., Glomerella cingulata (Stoneman) Spauld. \& Schrenk., Colletotrichum gloeosporioides Penz. or Colletotrichum acutatum J. H. Simmonds and Rhizopus stolonifer, respectively. Alternatives to chemical control, when used alone, are generally less effective than fungicides [1]. Therefore, it would be apt to combine several of these alternatives to equal the effectiveness of fungicides. In our present investigation, pre- or postharvest use of $\mathrm{Ca}$ in combination with $\mathrm{B}$ or salicylic acid 
resulted in reduced fruit decay. The least infection was noted in the treatment comprising preharvest spray of $\left[\mathrm{GA}_{3}+\right.$ salicylic acid] + postharvest [Ca EDTA dip + fungicide treatment]; however, non-fungicidal treatments entailing preharvest spray of $\left[\mathrm{GA}_{3}+\mathrm{Ca}\right.$ EDTA $]+$ postharvest salicylic acid dip, and preharvest spray of $\left[\mathrm{GA}_{3}+\right.$ salicylic acid] + postharvest salicylic acid dip were, statistically, equally efficient in reducing fruit decay (figure 7).

In our study, the treated fruits were crisper, sweeter, and visually more acceptable than untreated control fruits at the end of the study (table II). The highest scores were obtained by preharvest spray of $\left[\mathrm{GA}_{3}\right.$ + Ca EDTA] + post-harvest salicylic acid dip followed by preharvest spray of $\left[\mathrm{GA}_{3}+\right.$ salicylic acid] + post-harvest salicylic acid dip at the end of the storage period. The control registered higher values in terms of all sensory attributes earlier than the treated fruits. This could be attributed to delayed ripening as a result of hormonal or mineral interaction in treated fruits. Further, this can be explained as a consequence of retention of titratable acidity, and inhibition of the reduction of sugars and retention of fruit firmness [13]. The conclusion of this study is that, besides imparting physiological benefits to stored apples, treatments comprising combinations of $\mathrm{Ca}, \mathrm{B}, \mathrm{GA}_{3}$ and salicylic acid improved consumer acceptability.

\section{Conclusions}

The present study suggests that shelf life and fruit quality can be improved significantly in 'Oregon Spur' apples by treating fruits with combinations of nutrients and bio-regulators, rather than treating them with a single nutrient or bio-regulator. Fruit composition changes during storage were significantly influenced by pretreatments, such as concentrations of TSS, reducing sugars and total sugars, which were higher in treated fruits than in the control. These findings may point towards changes in enzymatic activities within the fruits, both pre- as well as postharvest. The application of salicylic acid along with $\mathrm{Ca}$ or $\mathrm{B}$ such as adopted in our present investigation suggests a potential alternative to common fungicides to reduce

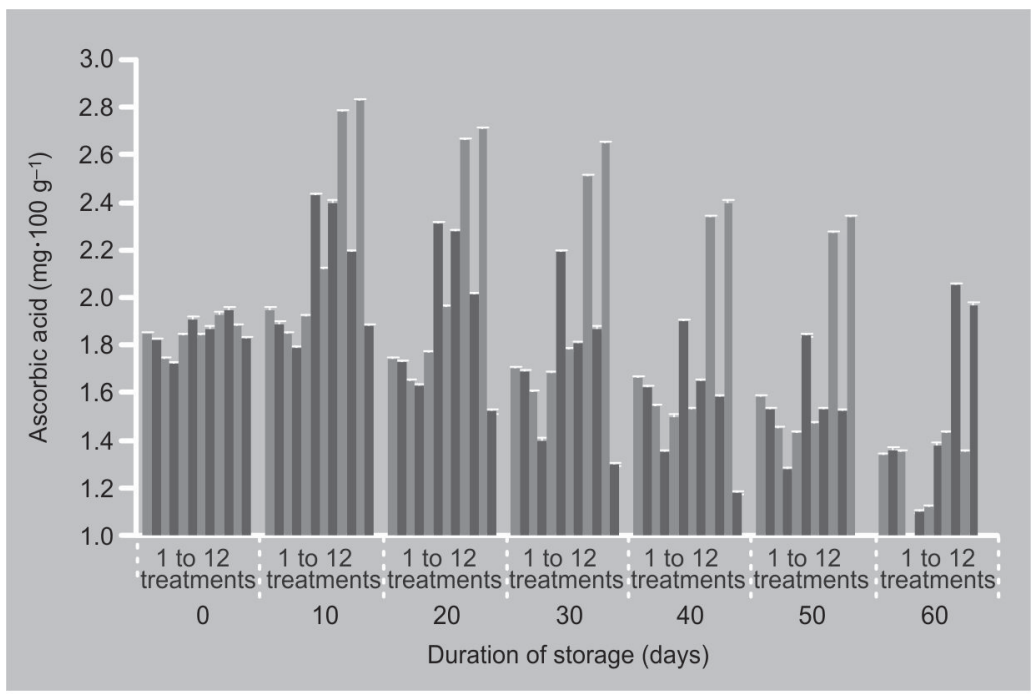

postharvest fruit decay. Our results vividly indicate that preharvest application of bioregulators and minerals, particularly salicylic acid, had positive impacts on fruit quality and shelf life of apple fruits. Moreover, keeping in mind the concerns of consumers regarding fungicide application to harvested fruits, use of salicylic acid and Ca EDTA dipping could be a possible choice to reduce the losses caused by pathogenic fungi. However, much needs to be done to verify these initial results, but, with this intermediate testimony of our progress, the prospect of using salicylic acid supplementation to improve fruit quality and shelf life of apple fruits appears a very possible proposition.

Figure 6.

Effect of different treatments (see table I) on ascorbic acid content of apple fruits during storage. Vertical bars represent standard error of the means.

Figure 7.

Variations in fruit spoilage as influenced by different treatments (see table $l$ ) at various days of storage. Vertical bars represent standard error of the means.

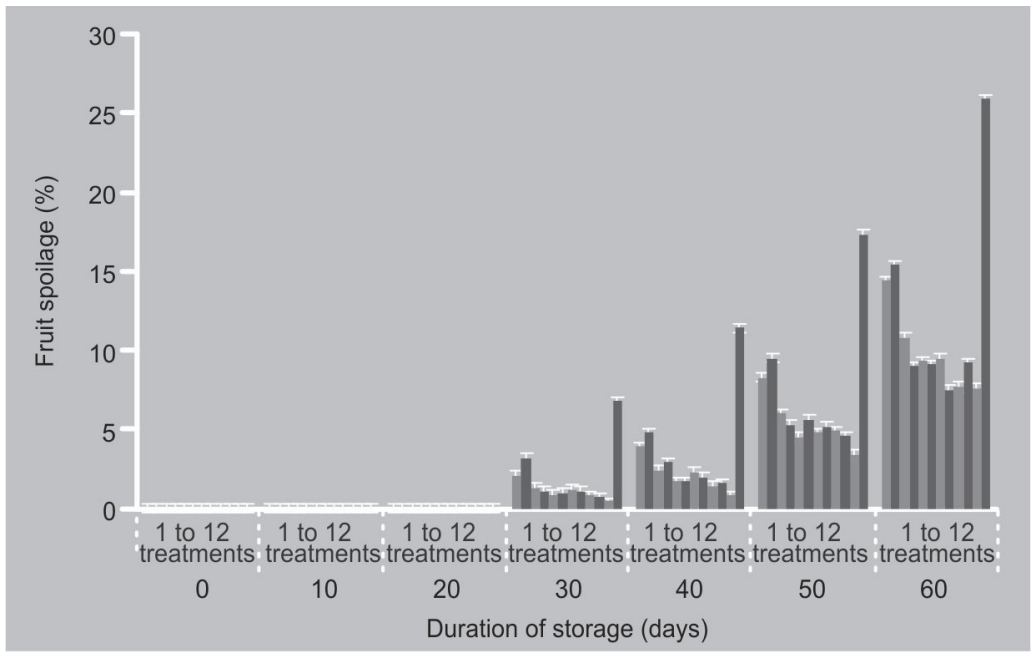


Table II.

Effect of pre- and postharvest treatments applied to apple fruits on the sensory scores of apple cv. Oregon Spur during storage ( $n=10$ panelists).

\begin{tabular}{|c|c|c|c|c|c|c|c|c|c|c|c|c|c|c|}
\hline \multirow[t]{3}{*}{ Treatment $^{1}$} & \multicolumn{7}{|c|}{ Appearance (\%) } & \multicolumn{7}{|c|}{ Taste (\%) } \\
\hline & \multicolumn{7}{|c|}{ Storage duration (days) } & \multicolumn{7}{|c|}{ Storage duration (days) } \\
\hline & 0 & 10 & 20 & 30 & 40 & 50 & 60 & 0 & 10 & 20 & 30 & 40 & 50 & 60 \\
\hline T1 & 90 & 94 & 91 & 86 & 81 & 71 & 59 & 82 & 85 & 86 & 80 & 76 & 68 & 60 \\
\hline T2 & 91 & 93 & 91 & 85 & 78 & 72 & 60 & 81 & 84 & 87 & 82 & 74 & 70 & 64 \\
\hline T3 & 90 & 95 & 92 & 84 & 81 & 73 & 64 & 80 & 86 & 86 & 84 & 79 & 75 & 70 \\
\hline T4 & 89 & 92 & 88 & 80 & 76 & 71 & 62 & 83 & 84 & 86 & 83 & 77 & 72 & 66 \\
\hline T5 & 92 & 97 & 93 & 88 & 84 & 78 & 67 & 82 & 85 & 87 & 83 & 78 & 74 & 68 \\
\hline T6 & 89 & 93 & 88 & 81 & 75 & 69 & 63 & 83 & 86 & 86 & 84 & 81 & 77 & 72 \\
\hline T7 & 92 & 95 & 90 & 84 & 80 & 74 & 68 & 82 & 85 & 87 & 84 & 80 & 76 & 71 \\
\hline T8 & 90 & 92 & 87 & 82 & 77 & 71 & 65 & 81 & 83 & 86 & 88 & 84 & 80 & 76 \\
\hline T9 & 91 & 98 & 95 & 89 & 85 & 78 & 73 & 82 & 85 & 87 & 89 & 86 & 84 & 80 \\
\hline T10 & 90 & 94 & 91 & 86 & 82 & 76 & 70 & 83 & 84 & 87 & 85 & 82 & 78 & 74 \\
\hline T11 & 92 & 98 & 94 & 90 & 86 & 80 & 72 & 82 & 84 & 86 & 88 & 85 & 82 & 78 \\
\hline T12 & 91 & 98 & 85 & 74 & 62 & 50 & 41 & 83 & 86 & 80 & 72 & 65 & 58 & 50 \\
\hline $\begin{array}{l}\text { LSD } \\
(P<0.05)\end{array}$ & 1.69 & 1.69 & 1.73 & 1.81 & 1.85 & 1.86 & 1.88 & 1.69 & 1.70 & 1.73 & 1.81 & 1.85 & 1.87 & 1.69 \\
\hline \multirow[t]{3}{*}{ Treatment $^{1}$} & \multicolumn{7}{|c|}{ Texture (\%) } & \multicolumn{7}{|c|}{ Flavor (\%) } \\
\hline & \multicolumn{7}{|c|}{ Storage duration (days) } & \multicolumn{7}{|c|}{ Storage duration (days) } \\
\hline & 0 & 10 & 20 & 30 & 40 & 50 & 60 & 0 & 10 & 20 & 30 & 40 & 50 & 60 \\
\hline T1 & 86 & 83 & 80 & 76 & 72 & 69 & 64 & 73 & 79 & 79 & 72 & 66 & 60 & 55 \\
\hline T2 & 87 & 83 & 81 & 77 & 73 & 70 & 66 & 74 & 78 & 80 & 74 & 68 & 63 & 57 \\
\hline T3 & 85 & 83 & 81 & 78 & 76 & 73 & 69 & 72 & 77 & 84 & 79 & 74 & 68 & 60 \\
\hline T4 & 87 & 84 & 82 & 77 & 74 & 71 & 67 & 73 & 78 & 82 & 76 & 70 & 65 & 58 \\
\hline T5 & 89 & 84 & 81 & 77 & 75 & 72 & 68 & 72 & 76 & 83 & 78 & 72 & 67 & 59 \\
\hline T6 & 86 & 84 & 82 & 80 & 78 & 75 & 71 & 74 & 76 & 86 & 82 & 76 & 70 & 64 \\
\hline T7 & 87 & 85 & 82 & 79 & 77 & 74 & 70 & 73 & 75 & 87 & 80 & 75 & 69 & 62 \\
\hline T8 & 88 & 86 & 84 & 82 & 80 & 78 & 74 & 72 & 74 & 86 & 84 & 78 & 74 & 66 \\
\hline T9 & 87 & 86 & 85 & 84 & 82 & 80 & 77 & 74 & 76 & 85 & 87 & 82 & 76 & 72 \\
\hline T10 & 89 & 87 & 85 & 83 & 80 & 76 & 72 & 73 & 75 & 84 & 85 & 80 & 75 & 68 \\
\hline T11 & 87 & 86 & 84 & 82 & 80 & 78 & 75 & 74 & 76 & 85 & 86 & 81 & 75 & 70 \\
\hline T12 & 86 & 82 & 75 & 70 & 64 & 58 & 49 & 74 & 82 & 75 & 70 & 64 & 57 & 50 \\
\hline $\begin{array}{l}\text { LSD } \\
(P<0.05)\end{array}$ & 1.69 & 1.73 & 1.81 & 1.73 & 1.81 & 1.84 & 1.87 & $\begin{array}{c}\text { Not } \\
\text { significant }\end{array}$ & 1.69 & 1.75 & 1.81 & 1.87 & 1.91 & 1.81 \\
\hline
\end{tabular}

\section{References}

[1] Conway W.S., Sams C.E., Hickey K.D., Pre and postharvest calcium treatment of apple fruits and its effect on quality, Acta Hortic. 594 (2002) 413-419.

[2] Wojcik P., Szwonek E., The efficiency of different foliar applied calcium materials in improving apple quality, Acta Hortic. 594 (2002) 563-567.

[3] Sanchez E.E., Righetti T.L., Effect of postharvest soil and foliar application of boron fertilizer on the partitioning of boron in apple trees, Hortscience 40 (2005) 2115-2117.

[4] Rajkumar M., Karuppaiah P., Kandasamy R., Effect of calcium and gibberellic acid on 
postharvest behaviour of papaya cv. Co2 Indian J. Hortic. 62 (2005) 327-331.

[5] Han T., Wang Y., Li L., Ge X., Effect of exogenous salicylic acid on post harvest physiology of peaches, Acta Hortic. 628 (2003) 583-589.

[6] Horvitz S., Godoy C., Camelo A.F.L., Yommi A., Application of gibberellic acid to 'Sweetheart' sweet cherries: effects on fruit quality at harvest and during cold storage, Acta Hortic. 628 (2003) 311-316.

[7] Singh B.K., Singh T.P., Effect of certain post harvest treatments on the storage life and quality of mango cv. Zardalu, Indian Food Pack. 46 (1992) 57-63.

[8] Cao J., Zeng K., Jiang W., Enhancement of postharvest disease resistance in $\mathrm{Ya}$ Li pear (Pyrus bretschneideri) fruit by salicylic acid sprays on the trees during fruit growth, Eur. J. Plant Pathol. 114 (2006) 363-370.

[9] Karagiannidis K., Thomidis T., Effect of boron products on development of rhizopus rots of peaches, An. Univ. Oradea, Fasc.: Prot. Mediu. 13 (2008) 197-199.

[10] Yao H., Tian S., Effects of pre and postharvest application of salicylic acid or methyl jasmonate on inducing disease resistance of sweet cherry fruit in storage, Postharvest Biol. Technol. 35 (2005) 253-262.

[11] Khalifa R.K.M., Hafez O.M., Abd-El-Khair H., Influence of foliar spraying with boron and calcium on productivity, fruit quality, nutritional status and controlling of blossom end rot disease of Anna apple trees, World J. Agric. Sci. 5 (2009) 237-249.

[12] Anon., Official methods of analysis of the Association of Analytical Chemists, 16th Ed., AOAC, Washington, DC, USA, 1995.

[13] Magazin N., Gvozdenovi D., Keserovi Z., Milic B., Fruit quality of Granny Smith apples picked at different harvest times and treated with 1-MCP, Fruits 65 (2010) 191-197.

[14] Kumar S., Kumar A., Baig M.J., Chaubey B.K., Effect of calcium on physico-chemical changes in aonla (Emblica officinalis Gaertn.), Indian J. Hortic. 62 (2005) 324-326.

[15] Plainsirichai M., Trinok U., Turner D.W., 1methylcyclopropene (1-MCP) reduces water loss and extends shelf life of fruits of Rose apple (Syzygium jambos Alston) cv. Tabtim Chan, Fruits 65 (2010) 133-140.

[16] Kathryn C.T., Brannen P., Effects of foliar calcium application on peach fruit quality, shelflife, and fruit rot, Albion ${ }^{\circledR}$ Conf. Plant Nutr., 2008, 1-11, http://www.metalosates.co.uk/ pdf/factsheet3.pdf

[17] Mills T.M., Behboudian M.H., Clothier B.E., Pre-harvest and storage quality of 'Braeburn' apple fruit grown under water deficit conditions, N.Z. J. Crop Hortic. Sci. 24 (1996) 159-166.

[18] Rong R.F., Tong S.S., Feng S.Q., Preliminary study on postharvest preservation of mango and tomato with salicylic acid, Food Sci. 22 (2001) 79-81.

[19] Barreiroa M.G., Lidonb F.C., Pinto M., Physicochemical characterization of the postharvest senescence of the winter melon 'Tendral', Fruits 56 (2001) 51-58.

[20] Dris R., Niskonen R., Calcium chloride sprays decrease physiological disorders following long-term cold storage of apple, Plant Foods Hum. Nutr. 54 (1999) 159-171.

[21] Han T., Li L.P., Physiological effect of salicylic acid on storage of apple in short period, Plant Physiol. Commun. 33 (1997) 347-348.

[22] Kher R., Bhat S., Effect of pre-harvest application of plant growth regulators $\left(\mathrm{GA}_{3}, \mathrm{NAA}\right.$ and $\mathrm{CCC}$ ) on postharvest quality of guava (Psidium guajava L.) cv. Sardar, J. Res. SKUAST-J 4 (2005) 88-95.

[23] Singh R., Sharma R.R., Tyagi S.K., Pre-harvest foliar application of calcium and boron influences physiological disorders, fruit yield and quality of strawberry (Fragaria $\times$ ananassa Duch.), Sci. Hortic. 112 (2007) 215220.

[24] Karlidag H., Yildirim E., Turan M., Exogenous applications of salicylic acid affect quality and yield of strawberry grown under antifrost heated greenhouse conditions, J. Plant Nutr. Soil Sci. 172 (2009) 270-276.

[25] Huang R., Xia R., Lu Y., Hu L., Xu Y., Effect of pre-harvest salicylic acid spray treatment on postharvest antioxidant in the pulp and peel of 'Cara Cara' navel orange (Citrus sinensis L. Osbeck), J. Sci. Food Agric. 88 (2008) 229-236. 
Efecto de los diversos tratamientos, aplicados antes y después de la cosecha, en la prolongación de la duración de vida de manzanas 'Oregon Spur'.

Resumen - Introducción. Las características de la calidad de los frutos se rigen por ciertos factores que intervienen antes de la cosecha, principalmente: el clima, la nutrición y los biorreguladores de las plantas. Estos dos últimos elementos pueden ser manipulados fácilmente con el fin de ayudar al productor. Asimismo, ciertas combinaciones de tratamientos después de la cosecha son aptas para mantener la calidad de los frutos durante el almacenamiento y la distribución. Se deduce que sería importante la adopción de un acercamiento general que permitiera combinar las prácticas antes o después de la cosecha, en vista de obtener una calidad máxima, así como la satisfacción del consumidor. Material y métodos. Se aplicaron diversas combinaciones de elementos minerales (calcio y boro) y de biorreguladores (ácido salicílico y ácido giberélico) a lotes de manzana, antes y después de la cosecha, para estudiar su influencia en el comportamiento de estos frutos después de la cosecha en el curso de un almacenamiento de 60 días en condiciones ambientales. Resultados y discusión. Entre los diferentes tratamientos testados, los frutos tratados - bien con ácido salicílico, bien con calcio - han visto mejoradas sus características físico-químicas y reducido su índice de infección. Entre todos los tratamientos testados, las combinaciones de productos químicos, aplicadas antes y después de la cosecha, han resultado ser las más apropiadas para mejorar la duración de conservación de las manzanas. La aplicación de ácido salicílico, en combinación con calcio o boro, permitiría disminuir el uso de fungicidas para luchar contra la degradación de las manzanas durante su almacenamiento.

India / Malus / frutas / calidad / almacenamiento / pérdidas postcosecha / tratamiento precosecha / tratamiento postcosecha / sustancias de crecimiento vegetal / Aptitud para la conservación 